\title{
Pengaruh Kontrol Diri Pengetahuan Keuangan dan Sikap Keuangan terhadap Perilaku Manajemen Keuangan pada Generasi Milenial
}

\author{
Mellysah*, Nurdin \\ Bandung, Indonesia. \\ *mellysc32@gmail.com,Psm_fe_unisba@yahoo.com
}

Prodi Manajemen, Fakultas Ekonomi dan Bisnis, Universitas Islam

\begin{abstract}
This study aims to determine the effect of self-control, knowledge and financial attitudes on financial management behavior in the millennial generation (Case Study on Community in Tanjung Batu Itam Village, Simpang Pesak District, East Belitung Regen cy, Bangka Belitung Province). The research method used in this research is quantitative associative. The data collection technique was using a closed questionnaire and a Likert scale. In this study, the population of the millennial generation in Tanjung Batu Itam Village was 1058 people and the samples obtained after meeting the sample selection criteria were 92 people. The sampling technique used in this research is purposive sampling. In this study, the analytical technique used is the classical assumption test, multiple linear regression, $\mathrm{t}$ test, $\mathrm{F}$ test, and the coefficient of determination. The results of data analysis in this study indicate that self-control, financial knowledge and financial attitudes partially on financial management behavior. Simultaneously self-control, financial knowledge, and financial attitudes affect the financial management behavior of the Millennial Generation in Tanjung Batu Itam Village, Simpang Pesak District, East Belitung Regency, Bangka Belitung Province.
\end{abstract}

Keywords: Self Control, Financial Knowledge, Financial Attitude, and Behavior of Financial Management.

\begin{abstract}
Abstrak. Penelitian ini bertujuan untuk mengetahui pengaruh kontrol diri, pengetahuan keuangan dan sikap keuangan terhadap perilaku manajemen keuangan pada generasi milenial (Studi Kasus Pada Masyarakat Di Desa Tanjung Batu Itam, Kec Simpang Pesak, Kab Belitung Timur, Provinsi Bangka Belitung). Metode penelitian yang digunakan dalam penelitian ini adalah kuantitatif asosiatif. Teknik pengumpulan data adalah dengan menggunakan kuesioner tertutup dan skala likert. Dalam penelitian ini jumlah populasi dari generasi milenial di Desa Tanjung Batu Itam adalah sebanyak 1058 orang dan sampel yang didapatkan setelah memenuhi kriteria pemilihan sampel adalah sebanyak 92 orang. Teknik sampel yang digunakan dalam penelitian ini adalah purposive sampling. Dalam penelitian ini teknik analisis yang digunakan adalah dengan menggunakan uji asumsi klasik, regresi linier berganda, uji t, uji F, dan koefisien determinasi. Hasil analisis data dalam penelitian ini menunjukan bahwa kontrol diri, pengetahuan keuangan dan sikap keuangan secara parsial berpengaruh terhadap perilaku manajemen keuangan. Secara simultan kontrol diri, pengetahuan keuangan, dan sikap keuangan berpengaruh terhadap perilaku manajemen keuangan pada Generasi Milenial di Desa Tanjung Batu Itam, Kec Simpang Pesak, Kab Belitung Timur, Provinsi Bangka Belitung.
\end{abstract}

Kata Kunci: Kontrol Diri, Pengetahuan Keuangan, Sikap Keuangan, dan Perilaku Manajemen Keuangan. 


\section{A. Pendahuluan}

Perkembangan ekonomi yang terus berkembang dari tahun ke tahun diseluruh dunia termasuk di negara Indonesia mengharuskan masyarakat untuk memiliki pengetahuan tentang keuangan serta dapat mengelola keuangan yang mereka miliki dengan sebaik mungkin. Perilaku manajemen keuangan bisa dibilang menjadi topik yang penting untuk dikaji karena perilaku manajemen keuangan merupakan hal yang penting bagi seluruh masyarkat atau pun individu dimana dapat menciptakan pemasukan dan pengeluaran yang seimbang, sehingga nantinya kebutuhan setiap individu akan terpenuhi.

Setiap individu harus memliki perilaku manajemen keuangan yang baik, dimana menurut Kholilah dan Irmani (2013) perilaku manajemen keuangan merupakan kemampuan seseorang dalam mengatur berbagai hal seperti perencanaan, penganggaran, pemeriksaan, pengelolaan, pengendalian, pencarian dan penyimpanan dana dalam kehidupan sehari-hari.

Kontrol diri atau locus of control merupakan cara pandang seseorang terhadap suatu peristiwa yang terjadi apakah individu tersebut dapat ataupun tidak dapat untuk mengendalikan peristiwa yang sedang terjadi.

Menurut Marsh (2006) menyatakan bahwa "pengetahuan keuangan merupakan pengetahuan yang mengacu pada apa yang diketahui individu tentang berbagai masalah yang berkaitan dengan keuangan pribadi, yang diukur menggunakan tingkat pengetahuan mereka tentang berbagai konsep keuangan pribadi.

Menurut Robbins, dkk (2013) menyatakan bahwa sikap adalah suatu pernyataan evaluasi yang bersifat baik ataupun buruk mengenai sebuah objek, orang maupun suatu kejadian.

Penelitian ini dilakukan untuk mengetahui bagaimana generasi milenial di Desa Tanjung Batu Itam berkaitan dengan perilaku manajemen keuangan yang mereka miliki apakah baik atau tidak, selain itu untuk mengetahui apakah kontrol diri, pengetahuan keuangan serta sikap keuangan berpengaruh terhadap perilaku manajemen keuangan yang baik.

Berdasarkan latar belakang yang telah diuraikan, maka perumusan masalah dalam penelitian ini sebagai berikut:

1. Bagaimana kontrol diri, pengetahuan keuangan dan sikap keuangan generasi milenial di Desa Tanjung Batu Itam?

2. Bagaimana perilaku manajemen keuangan pada generasi milenial di Desa Tanjung Batu Itam?

3. Bagaimana pengaruh kontrol diri, pengetahuan keuangan dan sikap keuangan terhadap perilaku manajemen keuangan secara simultan dan parsial pada generasi milenial di Desa Tanjung Batu Itam?

Selanjutnya, tujuan dalam penelitian ini diuraikan dalam pokok-pokok sebagai berikut:

1. Untuk mengetahui bagaimana kontrol diri, pengetahuan keuangan dan sikap keuangan generasi milenial di Desa Tanjung Batu Itam.

2. Untuk mengetahui bagaimana perilaku manajemen keuangan pada generasi milenial di Desa Tanjung Batu Itam.

3. Untuk mengetahui bagaimana pengaruh kontrol diri, pengetahuan keuangan dan sikap keuangan terhadap perilaku manajemen keuangan secara simultan dan parsial pada generasi milenial di Desa Tanjung Batu Itam.

\section{B. Metodologi Penelitian}

Peneliti menggunakan metode deskriptif dan verifikatif dengan menggunakan pendekatan kuantitatif. Populasi yang dipilih dalam penelitian ini adalah Generasi Milenial di Desa Tanjung Batu Itam yang berjumlah 1.058 orang. Dengan teknik pengambilan sampel yaitu teknik Purposive Sampling menggunakan perhitungan slovin dengan tingkat signifikan 10\% diperoleh jumlah sampel penelitian sebanyak 92 orang. Teknik pengumpulan data yang digunakan dalam penelitian ini adalah kuesioner atau angket online. Adapun teknik analisis data yang digunakan dalam penelitian ini adalah teknis analisis regresi linier berganda. 


\section{Hasil Penelitian dan Pembahasan}

Pengaruh Kontrol Diri (X1), Pengetahuan Keuangan (X2) dan Sikap Keuangan (X3) terhadap Perilaku Manajemen Keuangan (Y)

Berikut adalah penelitian mengenai pengaruh kontrol diri, pengetahuan keuangan dan sikap keuangan dengan perilaku manajemen keuangan. Hasil pengujian dijelaskan pada tabel 1.

Tabel 1. Uji F (Uji Simultan)

\begin{tabular}{|c|c|c|c|c|c|c|}
\hline \multicolumn{7}{|c|}{ ANOVA $^{a}$} \\
\hline \multicolumn{2}{|c|}{ Model } & Sum of Squares & $\mathrm{df}$ & Mean Square & $\mathrm{F}$ & Sig. \\
\hline \multirow[t]{3}{*}{1} & Regression & 247.319 & 3 & 82.440 & 37.679 & $.000^{\mathrm{b}}$ \\
\hline & Residual & 192.540 & 88 & 2.188 & & \\
\hline & Total & 439.859 & 91 & & & \\
\hline
\end{tabular}

Sumber: Data Diolah, 2021.

Berdasarkan tabel diketahui bahwa hasil dari F hitung $>\mathrm{F}$ tabel sebesar 37,679 $>2,15$ dan tingkat signifikan sebesar $0,000<0,10$. Sehingga, dapat disimpulkan bahwa H4 diterima dan variabel Kontrol Diri (X1), Pengetahuan Keuangan (X2), dan Sikap keuangan (X3) secara simultan berpengaruh terhadap Perilaku Manajemen Keuangan (Y). Karena, semua variabel independen dapat digunakan secara bersama-sama dalam menjelaskan variabel dependen.

Setelah mengetahui hasil dari uji F (uji simultan) berikut ini hasil dari uji t (uji parsial) dari setiap variabel, yaitu:

Pengaruh Kontrol Diri (X1) terhadap Perilaku Manajemen Keuangan (Y)

Berikut ini merupakan hasil dari uji t variabel kontrol diri (X1), yaitu:

Tabel 2. Uji t Variabel Kontrol Diri (X1)

\begin{tabular}{|c|c|c|c|c|c|c|}
\hline \multicolumn{7}{|c|}{ Coefficients $^{\mathrm{a}}$} \\
\hline & & \multicolumn{2}{|c|}{ Unstandardized Coefficients } & \multirow{2}{*}{$\begin{array}{c}\begin{array}{r}\text { Standardized } \\
\text { Coefficients }\end{array} \\
\text { Beta }\end{array}$} & \multirow[b]{2}{*}{$\mathrm{t}$} & \multirow[b]{2}{*}{ Sig. } \\
\hline \multicolumn{2}{|c|}{ Model } & $\mathrm{B}$ & Std. Error & & & \\
\hline \multirow[t]{2}{*}{1} & (Constant) & 8.500 & 1.228 & & 6.921 & .000 \\
\hline & Kontrol Diri & .624 & .097 & .562 & 6.441 & .000 \\
\hline
\end{tabular}

Sumber: Data Diolah, 2021.

Dari tabel diketahui bahwa variabel Kontrol Diri (X1) dengan tingkat signifikan sebesar $0,000<0,10$ atau $t$ hitung sebesar 6,441 $>\mathrm{t}$ tabel sebesar 1,663. Sehingga, dapat disimpulan bahwa H1 diterima dan secara parsial variabel Kontrol Diri (X1) berpengaruh terhadap variabel Perilaku Manajemen Keuangan (Y).

Pengaruh Pengetahuan Keuangan (X2) terhadapPerilaku Manajemen Keuangan (Y)

Berikut ini merupakan hasil dari uji t variabel pengetahuan keuangan (X2), yaitu:

Tabel 3. Uji t Variabel pengetahuan keuangan (X2)

\section{Coefficients $^{\mathrm{a}}$}




\begin{tabular}{|c|c|c|c|c|c|c|}
\hline \multirow{2}{*}{\multicolumn{2}{|c|}{ Model }} & \multicolumn{2}{|c|}{ Unstandardized Coefficients } & \multirow{2}{*}{$\begin{array}{c}\begin{array}{c}\text { Standardized } \\
\text { Coefficients }\end{array} \\
\text { Beta } \\
\end{array}$} & \multirow[b]{2}{*}{$\mathrm{t}$} & \multirow[b]{2}{*}{ Sig. } \\
\hline & & $\mathrm{B}$ & Std. Error & & & \\
\hline \multirow[t]{2}{*}{1} & (Constant) & 8.487 & .790 & & 10.747 & .000 \\
\hline & Pengetahuan Keuangan & .540 & .053 & .729 & 10.116 & .000 \\
\hline
\end{tabular}

Sumber: Data Diolah, 2021.

Dari tabel diketahui bahwa variabel Pengetahuan Keuangan (X2) dengan tingkat signifikan sebesar $0,000<0,10$ atau t hitung sebesar 10,116 $>\mathrm{t}$ tabel sebesar 1,663. Sehingga, dapat disimpulan bahwa H2 diterima dan secara parsial variabel Pengetahuan Keuangan (X2) berpengaruh terhadap variabel Perilaku Manajemen Keuangan (Y).

Pengaruh Sikap Keuangan (X3) terhadap Perilaku Manajemen Keuangan (Y)

Berikut ini merupakan hasil dari uji t variabel Sikap Keuangan (X3), yaitu:

Tabel 4. Uji t Variabel Sikap Keuangan (X3)

\begin{tabular}{|c|c|c|c|c|c|c|}
\hline \multicolumn{7}{|c|}{ Coefficients $^{\mathbf{a}}$} \\
\hline & & \multicolumn{2}{|c|}{ Unstandardized Coefficients } & \multirow{2}{*}{$\begin{array}{c}\begin{array}{r}\text { Standardized } \\
\text { Coefficients }\end{array} \\
\text { Beta }\end{array}$} & \multirow[b]{2}{*}{$\mathrm{t}$} & \multirow[b]{2}{*}{ Sig. } \\
\hline \multicolumn{2}{|c|}{ Model } & $\mathrm{B}$ & Std. Error & & & \\
\hline \multirow[t]{2}{*}{1} & (Constant) & 11.267 & .786 & & 14.336 & .000 \\
\hline & Sikap Keuangan & .875 & .132 & .572 & 6.618 & .000 \\
\hline
\end{tabular}

Sumber: Data Diolah, 2021.

Dari tabel diketahui bahwa variabel Sikap Keuangan (X3) dengan tingkat signifikan sebesar $0,000<0,10$ atau $\mathrm{t}$ hitung sebesar 6,618 $>\mathrm{t}$ tabel sebesar 1,663. Sehingga, dapat disimpulan bahwa H3 diterima dan secara parsial variabel Sikap Keuangan (X3) berpengaruh terhadap variabel Perilaku Manajemen Keuangan (Y).

\section{Kesimpulan}

Berdasarkan hasil dari pembahasan yang telah dikemukakan pada bab sebelumnya, dapat ditarik kesimpulan sebagai berikut :

1. Berdasarkan hasil dari penelitian yang telah dilakukan dan didapatkan data bahwa kontrol diri, pengetahuan keuangan dan sikap keuangan yang dimiliki oleh generasi milenial pada masyarakat di Desa Tanjung Batu Itam, Kec Simpang Pesak, Kab Belitung Timur, Provinsi Bangka Belitung menunjukan bahwa ketiga variabel tersebut berpengaruh signifikan terhadap perilaku manajemen keuangan generasi milenial pada masyarakat di Desa Tanjung Batu Itam, Kec Simpang Pesak, Kab Belitung Timur, Provinsi Bangka Belitung.

2. Dari data yang telah dikumpulkan dan diolah oleh penulis dapat diketahui bahwa perilaku manajemen keuangan dari genarasi milenial pada masyarakat di Desa Tanjung Batu Itam, Kec Simpang Pesak, Kab Belitung Timur, Provinsi Bangka Belitung sudah baik dan dari data tersebut dapat dilihat bahwa generasi milenial tidak hanya berfokus untuk keuangannya di masa sekarang akan tetapi, mereka juga memiliki tujuan keuangan yang baik untuk di masa yang akan datang.

3. Kontrol diri, pengetahuan keuangan dan sikap keuangan secara simultan berpengaruh terhadap perilaku manajemen keuangan Pada Generasi Milenial (Studi Kasus Pada Masyarakat Di Desa Tanjung Batu Itam, Kec Simpang Pesak, Kab Belitung Timur, Provinsi Bangka Belitung). Dimana H0 ditolak dan H4 diterima. Berdasarkan hasil dari uji $\mathrm{F}$ dimana $\mathrm{F}$ hitung lebih besar dari $\mathrm{F}$ tabel yaitu sebesar 37,679 > 2,15 dan tingkat 
$120 \mid$ Mellysah, et al.

signifikan lebih kecil dari 0,05. Hal ini berarti bahwa kontrol, pengetahuan keuangan dan sikap keuangan diri akan mempengaruhi perilaku manajemen keuangan.

\section{Acknowledge}

Maka dari itu penulis mengucapkan terimakasih sebesar-besarnya kepada berbagai pihak yang telah memberikan kontribusi dalam penelitian ini. Penulis berharap penelitian ini bisa bermanfaat bagi para pembaca.

\section{Daftar Pustaka}

[1] Al-Kholilah, N \& Iramani (2013). Studi Financial Management Behavior Pada Masyarakat Surabaya. Journal of Business and Bangking. 3(1): 69-80.

[2] Marsh, Brent A (2006). Examining The Personal Financial Attitude, Behavior and Knowledge Levels of First-Year and Senior Students at BaptistUniversities in The State Of Texas. Bowling Green State University.

[3] Robbins (2013). Perilaku Organisasi. Jakarta: Gramedia. 